\title{
Determinants of microfinance outreach in Sub-Saharan Africa: A panel approach
}

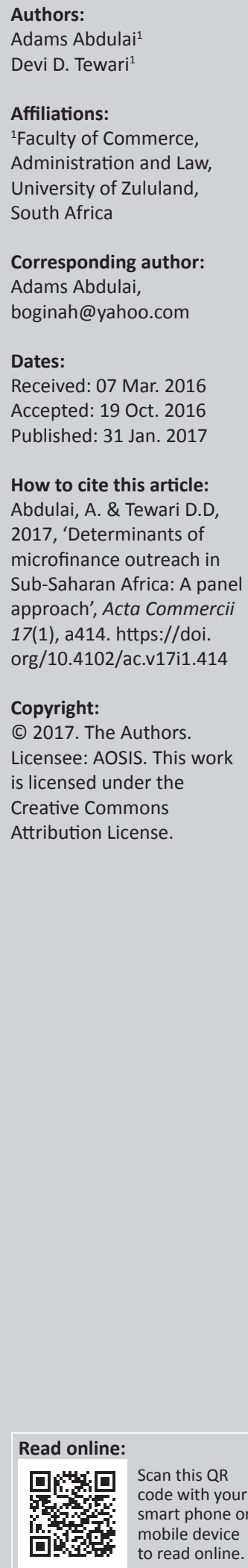

Orientation: The study focused on analysing the outreach performance of microfinance institutions (MFIs) in providing critical services for the poor using innovative lending techniques within constrained environments.

Research purpose: The study examined the trade-off relations between the depth and the breadth of outreach and identified institutional level factors that influence MFIs outreach in sub-Saharan Africa (SSA).

Motivation for the study: MFIs continue to play critical roles in extending financial services to the poor and yet previous studies have not analysed comprehensively the dimensions of outreach necessary for financial inclusion.

Research design, approach and methods: The study employed correlation analysis and random effects methodology to panel data regression analysis (619 observations, 71 MFIs across 10 countries) to establish the trade-off relations and the determinants of outreach in SSA.

Main findings: It was established that a trade-off exists between the depth of outreach (access to credit disbursement by poor clients) and breadth of outreach (number of clients served). The results further revealed that gross loan portfolio, portfolio at risk, borrower per staff member, interest rate, and operating expenses to assets ratio are the main institutional determinants of MFIs outreach in SSA.

Practical/managerial implications: The policy implication is that MFIs that concentrate efforts in reaching the relatively poor do so at the expense of reaching a large number of poor clients. We suggest that effective monitoring of depth and breadth and the adoption and implementation of cost-saving outreach technologies by MFIs could enable them to operate sustainably and efficiently.

Contribution/value added: A major contribution of the study is the trade-off relations revealed between the depth of outreach and the breadth of outreach of MFIs which advances the outreach literature.

\section{Introduction}

Microfinance institutions (MFIs) worldwide are striving to reach out to a large number of clients (breadth of outreach) and at the same time ensure coverage for those living with high relative poverty levels (depth of outreach) with financial services needed for both consumption and enterprise development. The breadth of outreach is related to the actual number of poor people reached with financial services, while the depth of outreach is how deep within the poor population an MFI is able to reach (serving the relatively poor and the marginalised). The main goal of microfinance is to ensure a massive reduction in poverty through institutions that are sustainable (Conning 1999; Cull, Demirguc-Kunt \& Morduch 2007). Thus, successful MFIs should satisfy both the social goal of reaching out to many more poor people and be able to sustain their business operations over a longer period of time financially. Reaching out to poorer clients on a sustainable base is possible and some MFIs such as Bancosol in Bolivia have demonstrated this in the past. However, the attainment of this double-line goal remains a challenge to most MFIs in recent times, and several studies (Cull, Demirguc-Kunt \& Morduch 2009; Paxton 2002; Quayes 2012; Zerai \& Rani 2011) that analysed the relationship between outreach, sustainability and efficiency reported various trade-offs.

Extension of microfinance services to more clients has received much attention in recent times following liberalisation of financial policies, adoption of better lending techniques, mobilisation of deposits and the application of communication technologies that reduce transaction costs in the 
microfinance sector. The exponential growth of the industry has contributed significantly to improved social welfare, job creation, enterprise development and the general financial health of most economies. Improvements in service delivery through the adoption of easy banking practices, for example, ATMs, Internet banking and mobile banking have made MFIs more efficient and sustainable (Hermes, Lensink \& Meesters 2011). The value of loan portfolios, number of savers and borrowers has recorded dramatic increases. Ledgerwood and White (2006) posit the annual growth rate of the industry to be between $15 \%$ and $30 \%$ worldwide. From 2004 to 2010, MFIs in SSA rose from 163 to 259 while the total number of clients increased from 8.7 million to 12.6 million, respectively (Consultative Group to Assist the Poor, CGAP 2005, 2012).

However, despite these achievements in outreach, up to $80 \%$ of the population in the African continent as well as most developing nations in other parts of the world still do not have access to basic financial services (African Union 2009; Cull et al. 2009). The continent continues to wallow in the path of under-development financially (Honohan \& Beck 2007). Microfinance which is seen as a poverty reduction tool has come under criticism in recent years for limited evidence of impacts on clients' lives and scale, despite claims of the fast expanding industry. For instance, Bateman (2014:5) described microcredit in South Africa as 'one of the most calamitous programme interventions in the post-apartheid era' for lack of impacts and the dangers it poses to the country's financial system. Yet, few studies have analysed the factors that influence microfinance outreach. Most of the existing studies (Ahlin, Lin \& Maio 2011; Hudak 2012; Vanroose 2008) that examined this subject matter approach it from the macroeconomic perspective. The only exception is the work of Osotimehin, Jegede and Akinlabi (2011), which examines the determinants of MFIs in South Western Nigeria using firm level variables. Analysing the factors that drive MFI outreach comprehensively is relevant as it would support both firm level and macro-level policy decisions that affect industrial operations of MFIs. This study, therefore, addresses two key questions: (1) Is there a trade-off between depth of outreach and breadth of outreach? (2) Which institutional level factors influence MFIs outreach in SSA? Understanding these dimensions of outreach is important in tackling the challenge of financial inclusion which is being pursued across continents. This study makes the first step in this direction by providing empirical evidence that sheds new insights on outreach performance of MFIs in SSA.

The rest of the study is organised as follows. Section 2 sets out the literature review. Section 3 presents our empirical estimation methods and data. Discussion of the empirical results is captured in Section 4 while Section 5 summarises and concludes the study.

\section{Literature review}

The theory of outreach posits that the poorer the borrowers served by an MFI, the better the outreach. In this regard, institutions that provide small loans to clients augment outreach (Jegede, Kehinde \& Akinlabi 2012; Schreiner 2002) since their primary target market are those living in poverty. The concept of outreach, though vague (Okumu 2007), is now being measured using acceptable variables. However, consensus on conceptual definitions for outreach is far from finalised. In this study, outreach is defined as the number of poor clients reached by MFI with high-quality financial products and services in a form that meets their needs.

Recognising the heterogeneity of the poor and designing products that meet their needs is critical in attaining MFI outreach goals. Difficulty however exists in measuring outreach due to the numerous definitions (Okumu 2007). For instance, Conning (1999:75) argued that 'reaching the poorest of the poor is more costly than reaching other segments of the market even when there are no fixed lending costs'.

Several measures of outreach have been proposed in the literature. Schreiner (2002) discussed six main dimensions of outreach and their measures to include depth, breadth, cost, worth, length and scope. The depth and breadth are the most commonly explored dimensions of outreach in most empirical analyses (Adhikary \& Papachristou 2014; Quayes 2012). This is due to the fast expansion in the sector which has led to increased breadth of outreach both at the firm and individual levels and has generated concerns among policy makers and practitioners regarding the depth of outreach and the overall social mission of MFIs. In addition, the unavailability of data on the other dimensions of outreach limits their usefulness in most empirical studies.

However, Paxton (2002) notes that outreach measures such as average loan size (ALS) only reflect the lending methodology rather than exclusion of individuals, and are therefore unsatisfactory as a measure of outreach. The depth of outreach index which incorporates clients' socioeconomic characteristics is perceived as a more appropriate measure. The breadth logic is nevertheless supported by Navajas et al. (2000) as many poor people compete for the few dollars in aid. Other measures of outreach proposed in the literature include the amount saved, the value of loan portfolio, a number of village posts, annual growth in MFI assets, women's participation, percentage coverage of rural population, and a variety of financial services offered (Yaron 1992). Ledgerwood (1999) proposed three dimensions for measuring outreach: loan outreach, clients and staff outreach, and savings outreach. In all these proposals, the central theme is to ensure that microfinance interventions are reaching the core poor.

A number of variables have been used to study MFIs outreach globally. The loan size is usually taken as a proxy for the depth of outreach, while the number of clients reached has been used to proxy breadth of outreach (Cull et al. 2007; Hermes et al. 2011). The assumption behind the loan size is reflected in the fact that smaller loan sizes suggest outreach to poorer clients. Zerai and Rani (2011) analysed the trade-off relations between outreach and sustainability using 2009 
data that cover 85 MFIs in India. The study used average loan balance as percentage of GNI (ALS) as a proxy for depth of outreach and the number of active borrowers (NAB) as a proxy for the breadth of outreach. By applying correlation analysis, they found no evidence of a trade-off between depth of outreach and operational sustainability of MFIs. However, a strong positive correlation was found between breadth of outreach and operational sustainability. Furthermore, the correlation between the number of female borrowers (an alternative proxy to the breadth of outreach) and operational sustainability was very weak.

Several empirical studies have examined MFIs outreach around the globe though much still needs to be done in the context of SSA. In general, studies find the determinants of outreach to include the funding source, governance and ownership structure, macroeconomic and political environment, population density, loan contract terms, the cost of service delivery and delivery mechanism (Jensen 2003; Ledgerwood 1999). Navajas et al. (2000) investigated the depth of outreach of MFIs in La Paz, Bolivia. They found that: (1) improved social welfare from microfinance depends on the dimensions of outreach; (2) lenders tended to serve those near the poverty line not the poorest; (3) deeper outreach comes from group lending as opposed to individual lending; and (4) deeper outreach is associated with rural lenders than with urban lenders. This suggests that lending methodology and client location influence the depth of outreach. However, the question of whether lenders had deep outreach in the study remained as the demand distribution and creditworthiness on supply is unknown.

Awusabo-Asare et al. (2009) analysed the outreach structure of MFIs in Ghana using the microfinance poverty assessment tool. The authors compared data from 1104 non-clients to 1600 clients and computed household level relative poverty scores. They discovered that rural and community banks and financial NGOs had greater outreach to all categories of clients (from extremely poor to the poor) compared to savings and loan companies, susu ${ }^{1}$ collectors and credit unions. Furthermore, the source of funds, outreach strategy and mission of the institutions influence their performance. Similarly, Osotimehin et al. (2011) examined the determinants of MFIs outreach in South Western Nigeria using panel data obtained from 80 institutions for the period 2005-2010. Employing generalised least square and ordinary least square regression analyses, the study found that ALS, debt to equity ratio, loan repayment rates and salary are the main positive determinants of outreach.

The presence of social networks has also been found to have an influence on MFI outreach. Wydick, Karp and Hilliker (2011) investigated the factors that influence MFIs outreach focusing on the role of social networks in enabling access to loans. By applying this information to 465 households in

1.They are individuals operating in the informal sector who collect savings on daily or weekly basis from micro entrepreneurs and market venders for safe keeping. Though not technically involved in mediating the aggregate funds mobilized, they manage withdrawals and are formally recognized in Ghana.
Guatemala, the study found evidence that households' access to credit is associated with being a member of a church network. Moreover, Mersland and Strom (2016) reported that MFIs with tailored lending to women are less profitable and inefficient. This supports previous evidence by Hermes et al. (2011) who found serving the poor as well as female borrowers to be less efficient.

Togba (2012) analysed the Ivorian credit market to understand the determinants of the choice for credit from formal and informal sources. The results show that loan size, agricultural purpose, geographical location of household and ethnicity are factors influencing the choice for formal services of credit. The study also found that low-income households tended to prefer small-size loans obtained from informal sources than formal sources. Previously, Youssoufou (2000) in his assessment of MFIs' outreach in Burkina Faso found that their outreach was very low in relation to the potential demand because of their inability to mobilise savings services. Evidence of non-viability and unsustainability of MFIs because of high dependence on subsidies and lowinterest rates charged to clients was also reported. This suggests that interest rates, savings mobilisation and subsidy levels influence MFIs outreach.

Piot-Lepetit and Nzongang (2014) analysed the double bottom line of MFIs' sustainability and outreach using a network of village banks in Cameroon. By applying the multi-DEA approach, the study found some $\mathrm{MC}^{2}$ (Mutuelles Communautuires de Croissance) attaining both the sustainability and outreach goals signifying efficient management by these MFIs. While a trade-off exists for $15 \%$ of the MFIs, $46 \%$ of the MFIs show no trade-off and the remaining 39\% were found to be inefficient in both financial and social dimensions. Similarly, using random effects (RE) and error components two-stage least squares (EC2SLS) methodology, Kar (2013) find a significantly positive relation between MFI size and average loan amount, suggesting the possibility of mission drift though not very explicit.

Adhikary and Papachristou (2014) in analysing the financial performance and outreach of 133 South Asian MFIs found the depth of outreach to relate positively to financial performance, suggesting that MFIs on sustained financial expansion paths can reach their social goal at minimised risk. Furthermore, both breadth and depth of outreach were found to be positively related to profitability and efficiency. Bos and Millone (2014) show that some MFIs effectively combine both depth and breadth of outreach and operated efficiently. They, however, note that decreases in efficiency occur as the loan portfolio becomes larger. Previously, Vanroose and D'Espallier (2013) studied the relationship between MFIs outreach performance and financial sector development. They found that MFIs were reaching more clients and operated profitably in countries with low access to banking services. Their findings support the market failure hypothesis which stipulates that MFIs respond to needs not satisfied by banks and flourish where bank failures occur. 
However, Sagamba, Shchetinin and Nurmukhammed (2013) in a case for Burundi found that the allocation of microloans was slightly in favour of the less advantaged, the main determinant being the quality of the projects funded.

Macroeconomic and institutional level factors have also been shown to drive MFIs performance in varied ways (Ahlin et al. 2011; Kai \& Hamori 2009; Vanroose 2008). These studies document the importance of the macro environment on MFIs' outreach performance. Ahlin et al. (2011) examined the linkage between macroeconomic and macro-institutional factors on MFIs success using data from 373 institutions. They discovered that a country's specific environment is a key factor that influences the performance of MFIs. Also, microfinance performance helps to boost development of the larger economy. Similarly, Imai et al. (2012) investigated microfinance impacts on poverty in the macro context using cross-country panel data from 48 nations. They found that lower levels of poverty indices are associated with higher gross loan portfolio (GLP) per capita, suggesting that microfinance has positive impacts on poverty reduction at the national level.

Hudak (2012) examined the impacts of financial sector development and regulation on microfinance outreach using the fixed effects methodology for 2006-2009. The results show that microfinance benefits more people in developing countries under favourable business environments. Previously, Vanroose (2008) explored the factors that drive MFIs outreach using macro data for 115 countries. The evidence shows that developing countries with higher income levels drive greater impacts from microfinance interventions than those with lower incomes. The density of population was found to positively influence MFIs outreach while the rates of inflation and industrialisation level do not.

\section{Methodology and data description}

A number of approaches are available for panel data analysis. The most common approaches are the fixed effects (FE) and RE methodologies (Greene 2005). In recent research works such as Adhikary and Papachristou (2014), Hartarska and Nadolnyak (2007), extensions have been made to these two models to cover instrumental variable estimation and the generalised method of moment estimation aimed at addressing issues of endogeneity satisfactorily. Nonetheless, the underlying assumptions regarding the data-generating process help in model selection.

This study follows the RE methodology which is relevant for performance analysis. The approach uses different intercept terms for the firms which are constant over time. The key assumption is that both the dependent and independent variables are the same cross-sectionally and temporally and variation across firms occurs through random factors and errors in measurement (Brooks 2008:536). The approach is more relevant when firms are selected randomly from a population. The model is said to produce more efficient estimates compared to the FE approach as within transformations are not required and degree of freedom problems are absent. The RE methodology accounts for all unobserved firm-specific residual variation in performance, thus, averting potential bias resulting from omitted variables (Stock \& Watson 2007). Furthermore, the potential to accommodate time-invariant variables compared to the FE model which simply eliminates them at first difference have been found in empirical studies (Hartarska 2005; Hermes \& Lensink 2011). However, the RE approach is valid only when there is no correlation between the regressors and the unobserved firm-specific effects.

In the empirical estimation, the study investigated both depth of outreach and breadth of outreach using ALS, the NAB and percentage of female borrowers (PFB) as dependent measures. Equation [1] is the empirical model for depth of outreach and ALS is used as the dependent measure. Equations [2] and [3] are models for the breadth of outreach by MFIs and NAB, and PFB is used as dependent measures. The independent variables of choice are based on the widely used measures for microfinance outreach efforts as documented in the literature. The empirical models estimated are presented as follows:

$$
\begin{aligned}
\operatorname{InALS}_{i t}= & \delta_{0}+\delta_{1} \operatorname{InPAR}_{i t}+\delta_{2} \operatorname{InGLP}_{i t}+\delta_{3} \operatorname{InROA}_{i t}+\delta_{4} \operatorname{InOEA}_{i t} \\
& +\delta_{5} \operatorname{InOSS}_{i t}+\delta_{6} \operatorname{InYLD}_{i t}+\delta_{7} \operatorname{InROE}_{i t}+\delta_{8} \operatorname{InBSM}_{i t}+u_{i t}
\end{aligned}
$$

[Eqn 1]

$$
\begin{aligned}
\operatorname{InNAB}_{i t}= & \beta_{0}+\beta_{1} \operatorname{InPAR}_{i t}+\beta_{2} \operatorname{InGLP}_{i t}+\beta_{3} \operatorname{InROA}_{i t}+\beta_{4} \operatorname{InOEA}_{i t} \\
& +\beta_{5} \operatorname{InOSS}_{i t}+\beta_{6} \operatorname{InYLD}_{i t}+\beta_{7} \operatorname{InROE}_{i t}+\beta_{8} \operatorname{InBSM}_{i t}+u_{i t}
\end{aligned}
$$

$$
\begin{aligned}
\operatorname{InPFB}_{i t}= & \gamma_{0}+\gamma_{1} \operatorname{InPAR}_{i t}+\gamma_{2} \operatorname{InGLP}_{i t}+\gamma_{3} \operatorname{InROA}_{i t}+\gamma_{4} \operatorname{InOEA}_{i t} \\
& +\gamma_{5} \operatorname{InOSS}_{i t}+\gamma_{6} \operatorname{InYLD}_{i t}+\gamma_{7} \operatorname{InROE}_{i t}+\gamma_{8} \operatorname{InBSM}_{i t}+u_{i t}
\end{aligned}
$$

where $\delta_{0} \beta_{0} \gamma_{0}$ are the intercepts, and $\delta_{1}-\delta_{8^{\prime}} \beta_{1}-\beta_{8}$ and $\gamma_{1}-\gamma_{8}$ are the coefficients of the parameters to be estimated. $u_{\mathrm{it}}$ is the error term and is assumed to have normal distribution. $u_{\mathrm{it}} \sim I I D\left(0, \sigma^{2}\right)$. All variables are taken in their logarithm form.

Average loan size as a percentage of gross national income (GNI) per capita (ALS) has been used as a proxy for depth of outreach in a number of studies (Cull et al. 2007; Hermes et al. 2011). Small-size loan reflects outreach to poorer clients by MFIs (greater depth). However, following competition in the marketplace and the drive for profitability, MFIs have been found to curtail lending to poor clients in favour of the relatively wealthier clients ready to take up larger loans. Studies have also shown that poor customers with good credit history tend to benefit from larger loans from institutions as a way to cut down the cost of service delivery. Based on this, ALS is expected to relate negatively to the depth of outreach and positively to the breadth of outreach. 
The outreach dimension of an MFI is influenced by its clientele base. The NAB is a prominent measure of the breadth of outreach. Small-sized institutions naturally have lesser outreach so we expect NAB to relate positively to the breadth of outreach. In addition, the proportion of women borrowers has been found to be high $(62 \%)$ as microfinance clients in Africa. This is significant in view of the rapid expansion of the sector. We use the PFB as a second dependent variable for breadth to help distinguish between the general outreach of MFIs from that of outreach focus on women. Both variables are expected to have positive impacts on MFI activities.

The study included a number of institutional level variables assumed to have an impact on MFIs outreach based on literature review as independent variables. Borrower per staff member (BSM) is a productivity measure that captures the level of staff performance. A productive MFI should have positive impacts on outreach to clients. Credit risk has been identified as one key factor that drives down the profitability of MFIs in SSA (CGAP 2010). Portfolio at risk (PAR) which is measured as the proportion of loans overdue for repayment after 30 days have passed is included to assess the performance of management in loan recovery. Higher PAR values typically reflect management inefficiency in loan collections, hence, deterioration of the loan portfolio quality. A negative relationship is expected between PAR and MFI outreach.

A well-sustained MFI can have greater outreach to the poor. Operational self-sufficiency (OSS) measures MFIs' ability to cover operating costs using revenues generated and we expect a positive relationship with outreach. Financial performance of institutions also drives their level of outreach and return on assets (ROA), and return on equity (ROE) is included to measure profitability. The generation of positive returns can greatly impact on the social mission of institutions through investments in improved technology that enhances cost efficiency in service delivery to poorer clients. At the same time, MFIs can adopt a turnover strategy by serving more clients with smaller loan sizes and in the process achieve high clients per employee ratios. Thus, better labour productivity performances can result from socially oriented programmes (Morduch, Hashemi \& Littlefield 2003).

Interest gained from operations is necessary not just to cover the cost of operations and satisfy the interest of shareholders but also to expand infrastructure and improved upon the quality of service delivery. However, the positive role of interest in expanding the frontiers of institutions while recognised has received mixed reactions in microfinance. The yield on gross portfolio (YLD) is used to proxy MFIs lending interest rate to clients. Market-based interest rates as argued by the welfarist are more likely to limit the economic participation of the poor in microfinance markets as they cannot afford such high-interest rates. Rising interest rates are expected to lead to a decline in microfinance outreach to the poor.
Furthermore, the loan portfolio of MFIs represents its biggest asset. A higher GLP reflects the size of the institution, which greatly determines its level of outreach. We expect a positive relationship between GLP and outreach. Finally, higher operating expense has been found to plague the operations of MFIs in SSA (CGAP 2010). Operating expenses to assets ratio (OEA) is measured as the ratio of adjusted operating expenses to the adjusted average GLP. It is a cost side variable and captures the cost implications associated with reaching out to the poor. Studies (Oteng-Abayie, Amanor \& Frimpong 2011; Rao 2002) have shown that MFIs operating costs average between $50 \%$ and $60 \%$ and this is likely to have an impact on outreach. OEA is expected to be negatively related to outreach.

\section{The data set}

Data for this study were obtained from the Microfinance Information Exchange (MIX) market database, a global database that provides information on MFIs activities. The data source provides standard financial performance indicators and audited financial statements from MFIs covering all regions and is reliable, comparable and publicly available. $^{2}$ All data posted to the site are reviewed and validated in line with standard business practices and audit rules. Previous studies in microfinance that used this database include Quayes (2012), Ahlin et al. (2011), Hermes et al. (2011) and Cull et al. (2007). Our study covered 10 countries in SSA (see Appendix 1, Table 1-A1 for a list of countries and MFIs), and selection was done purposively based on the level of microfinance activities and data availability for the study period (2003-2013). Out of 387 MFIs that reported to the database during the period for the countries considered, 71 MFIs were selected based on the quality and completeness of the data supplied (only MFIs rated between 3 and 5 diamonds ${ }^{3}$ by rating agencies were included in our analysis). This ensured that only MFIs with quality financial statements and completed data sets that have been audited are used. One limitation of this data source is that it does not capture all MFIs since reporting to the database is not obligatory. Nonetheless, it is currently the best available database for microfinance.

\section{Empirical results and discussion}

The analysis relied on the RE methodology for panel data analysis. All the necessary initial robust checks were carried out prior to estimation. Significance levels and the sign of the coefficients estimated from the regression models were used to evaluate the validity and reliability of the estimated models. Correlation analysis was used to establish the relations between variables and only those that show significant relations were included in the regression analysis. This ensures that only relevant variables were captured in the estimated models. Results of the study were compared with

2.MiX market data is available online at www.mixmerket.org. As of the year 2015, the data became available on sale and are no longer free.

3.Diamonds are used to rate the quality of financial statements and reports submitted by MFIs. The values range from $1-5$ with five being the highest. A MFI rated 5 implies that its data set is complete with audited financial statements. 
TABLE 1: Descriptive statistics of variables used in the study.

\begin{tabular}{lc}
\hline Variable & 6 \\
\hline Operational self-sufficiency (OSS) & 3 \\
Average loan balance as percentage of GNI (ALS) & 607 \\
Number of active borrowers (NAB) & 278 \\
Percentage of female borrowers (PFB) & 619 \\
Peturn on assets (ROA) & \\
Return on equity (ROE) & 6 \\
Yield on gross loan portfolio (YLD) & 297 \\
Gross loan portfolio (GLP) & 300 \\
Operating expense to assets ratio (OEA) &
\end{tabular}

\begin{tabular}{lcccc} 
Obs & Mean & Standard deviation & Minimum & Maximum \\
\hline 619 & 1.065642 & 0.489764 & 0.033100 & 8.415800 \\
306 & 0.310063 & 0.284420 & -1.139800 & 1.510900 \\
607 & 56242.99 & 122222.4 & 72.0 & 801809.0 \\
278 & 0.051022 & 0.164639 & -0.103800 & 1.79000 \\
619 & -0.85303 & 1.277613 & -19.06 & 0.8870544 \\
538 & 0.089826 & 0.110023 & 0.000500 & 0.830000 \\
275 & -0.083967 & 0.962199 & -14.09000 & 0.930000 \\
619 & 0.538745 & 2.310005 & -1.620000 & 18.21000 \\
619 & 6.695118 & 0.8661559 & 0 & 9.533747 \\
297 & 161.6431 & 128.6933 & 0 & 809.0 \\
300 & 2.306562 & 10.83155 & 0.164400 & 86.46000 \\
\hline
\end{tabular}

Source: Based on MIX market data

other studies documented through the literature review. Descriptive statistics of the variables used, correlation analysis for trade-off relations and results from the RE regressions are presented in this section.

Table 1 reports summary statistics of the variables included in the study. The mean of most variables can be interpreted as the percentage of firms in the category (except OSS). For example, the ALS of MFIs is about $31 \%$ of respective country's gross national income (GNI) per capita on average. This figure compares favourably with the $15.3 \%$ reported for Africa in 2003 , reflecting an increase over the period. The institutions demonstrate a low level of portfolio quality with an average PAR over 30 days of $8.9 \%$. This suggests a worsening situation in loan recoveries and that management needs to take collective action to improve loan repayments and enhance outreach. In addition, it is shown that MFIs charge on average a $53.8 \%$ interest rate on loans and the number of active clients served my MFIs on average is 56243 members.

The asset allocation of all MFI types shows that GLP represents $66.9 \%$ of assets. This can be said to be fairly good with potential impacts on MFIs' social and financial performance. However, the institutions are not profitable as the average ROA is negative (85\%). Mori et al. (2015) observed similar negative returns on assets for MFIs in East Africa. This could be because of the diverse nature of the industry as most MFIs in SSA are made up of cooperatives and NGOs with dominant social performance goals. MFIs on average also post-negative returns on equity (8.3\%). However, for OSS, values below 1 indicate that the respective MFI is not covering costs from operating revenues. The sampled MFIs are operationally sustainable as revealed by OSS.

Prior to estimation, we performed a number of diagnostic tests which aid in model selection and accuracy of the estimated parameters. The results from panel unit tests using the Fisher-ADF method show the absence of unit roots. The Fisher-ADF tests are more robust than other test approaches such as the Im, Pesaran and Shin. Furthermore, variance inflation factor analysis was done for all independent variables used in the study to check for multicollinearity. The test scores usually range from 1 to infinity and values greater
TABLE 2: Hausman specification test: fixed effects vs. random effects for microfinance institutions outreach.

\begin{tabular}{lccc}
\hline Variable & \multicolumn{3}{c}{ Coefficients } \\
\cline { 2 - 4 } & $\begin{array}{c}\text { Fixed } \\
\text { effects (b) }\end{array}$ & $\begin{array}{c}\text { Random } \\
\text { effects (B) }\end{array}$ & $\begin{array}{c}\text { Difference } \\
\text { (b-B) }\end{array}$ \\
\hline Portfolio at risk (PAR) & -0.1380452 & -0.1821369 & 0.0440917 \\
Gross loan portfolio (GLP) & 0.5802773 & 0.6006268 & -0.0203496 \\
Operating expense to assets ratio (OEA) & 0.050733 & 0.0595972 & -0.0088643 \\
Borrower per staff member (BSM) & 0.337593 & 0.3877897 & -0.0501967 \\
Yield on gross loan portfolio (YLD) & 0.0927061 & 0.0416677 & 0.0510384 \\
Operational self-sufficiency (OSS) & -0.0603183 & 0.0150964 & -0.0754147 \\
Return on equity (ROE) & -0.0076815 & -0.0065369 & -0.0011446 \\
Return on assets (ROA) & 0.0253867 & 0.0317405 & -0.0063538 \\
\hline
\end{tabular}

Source: Estimation based on MIX market data

Note: Ho: difference in coefficients not systematic chi2 $(8)=(b-B)^{\prime}\left[\left(V_{-} b-V \_B\right)^{\wedge}(-1)\right](b-B)=22.89$, Prob > chi2 $=0.0035$.

than 10 are indications of severe multicollinearity problems. Our test results obtained ranged from 1.02 to 1.49 , which show low levels of multicollinearity. The Hausman test for model specification based on the difference in coefficients between the FE and RE models upholds the appropriateness of the RE model as the $p$-value obtained from the test is not less than $1 \%$ (see Table 2 ).

\section{Results of correlation analysis}

Table 3 shows the presence of significant trade-offs from the correlation analysis. The first is the trade-off between sustainability and wider outreach as proxied by the NAB. This means that institutions that focus on attaining the financial sustainability goal are unlikely to provide microfinance products and services to a large number of poor clients who require them. This could worsen the access-to-financial-services situation of the poor, leading to their exclusion from microfinance markets. The result supports previous evidence (Cull et al. 2009; Quayes 2012) on trade-off relations. Second, the most striking result is the trade-off between depth of outreach and breadth of outreach. This means that in the attainment of the social goal, institutions make deliberate choices as to which segment of the poor population to target. As pointed out by Conning (1999), MFIs that target the 'low end' of the market segment of the poor are less profitable and may not be sustainable. The results support this proposition, suggesting that MFIs that strive to reach the relatively poor do so at the expense of reaching a large number of poor borrowers with 
financial services. The policy implication is that managers of MFIs and board of directors should strive to create a balance between the two dimensions of outreach in their programming. Another interesting trade-off which emerged is that between profitability, sustainability and outreach for the institutions. These various trade-offs confirm the occurrence of mission drift in the microfinance sector in SSA. This could be because of industry evolutions that have caused institutions to strategically move towards commercialisation for sustainability purposes rather than pursuing the poverty alleviation goals initially conceived for the industry. For the majority of poor people who desire financial products and services, this is bad news. However, to policy makers, MFI networks and managers of these institutions, this calls for pragmatic action to restore hope for the poor.

\section{Results of random effects regression analysis}

The RE regression results for the institutional determinants of MFIs outreach are presented in Table 4 . The parameter Rho which shows the ratio of individual specific error variance to the composite error term indicates the goodness of fit for the estimated models. Based on this parameter, model [1] is the best among the three estimated models as it explains a high proportion $(71 \%)$ of the entire variance in the composite error term.

OSS has a positive coefficient in all three models but is not statistically significant. This suggests that the sustainability level of MFIs do not really drive outreach. This could be attributed to receivable subsidies as most institutions (48.2\%) covered in the study are memberbased, typical of the industry in SSA. This finding contradicts Zerai and Rani (2011) who found strong positive relations between OSS and breadth of outreach. PAR positively and significantly influences depth of outreach but negatively influences breadth of outreach as measured by the NAB. This shows that deeper outreach contributes to worsening portfolio quality while wider outreach reinforces it. This result contradicts Adhikary and Papachristou (2014) finding that depth, as opposed to breadth, mitigates risk. The significantly negative relationship between PAR and breadth of outreach, however, supports the findings of Crabb (2008). The need

TABLE 3: Correlation analysis results for microfinance institutions outreach

\begin{tabular}{|c|c|c|c|c|c|c|c|c|c|c|c|}
\hline Variable & NAB & ALS & PFB & oss & ROA & PAR & ROE & YLD & GLP & OEA & BSM \\
\hline NAB & 1.000 & - & - & - & - & - & - & - & - & - & - \\
\hline ALS & $-0.0896 * *$ & 1.0000 & - & - & - & - & - & - & - & - & - \\
\hline PFB & 0.0445 & $-0.2614 * * *$ & 1.0000 & - & - & - & - & - & - & - & - \\
\hline OSS & $0.2348 * * *$ & 0.0637 & 0.0010 & 1.0000 & - & - & - & - & - & - & - \\
\hline ROA & -0.0319 & $-0.1286 * * *$ & $-0.1345 * * *$ & $-0.1699 * * *$ & 1.0000 & - & - & - & - & - & - \\
\hline PAR & $-0.2693 * * *$ & $0.1170 * * *$ & $-0.0864 * *$ & $-0.1982 * * *$ & 0.0073 & 1.0000 & - & - & - & - & - \\
\hline YLD & $-0.2303 * * *$ & $-0.1795 * * *$ & $0.1129 * * *$ & $-0.0792^{*}$ & $0.0935 * *$ & $0.1040 * * *$ & $0.1096 * * *$ & 1.0000 & - & - & - \\
\hline GLP & $0.5968 * * *$ & $0.3471 * * *$ & $-0.0864 * *$ & $0.3144 * * *$ & $-0.0943 * *$ & -0.0393 & 0.0137 & $-0.2712 * * *$ & 1.0000 & - & - \\
\hline OEA & $-0.1312 * * *$ & $-0.1844 * * *$ & $0.2219 * * *$ & $-0.1918 * * *$ & $0.0710^{*}$ & 0.0227 & 0.0310 & $0.2826 * * *$ & $-0.1645 * * *$ & 1.0000 & - \\
\hline BSM & $0.3348 * * *$ & $-0.3296 * * *$ & $0.1293 * * *$ & 0.0357 & $-0.1133 * * *$ & $-0.1674 * * *$ & -0.0312 & $-0.1564 * * *$ & 0.0036 & $-0.2182 * * *$ & 1.0000 \\
\hline
\end{tabular}

Source: Estimation based on MIX market data

NAB, Number of active borrowers; ALS, Average loan balance as percentage of GNI; PFB, Percentage of female borrowers; OSS, Operational self-sufficiency; ROA, Return on assets; PAR, Portfolio at risk; ROE, Return on equity; YLD, Yield on gross loan portfolio; GLP, Gross loan portfolio; OEA, Operating expense to assets ratio; BSM, Borrower per staff member.

Statistical significance: $*,<0.10 ; * *,<0.05 ; * * *,<0.01$.

TABLE 4: Random effects results of the determinants of outreach (Dependent: ALS, NAB, PFB).

\begin{tabular}{|c|c|c|c|}
\hline \multirow[t]{2}{*}{ Particulars } & \multicolumn{3}{|c|}{ Coefficients } \\
\hline & Model [1]: ALS & Model [2] :NAB & Model [3]: PFB \\
\hline Operational self-sufficiency (OSS) & $0.0731993(1.05)$ & $0.0150964(0.09)$ & $0.0306084(0.44)$ \\
\hline Portfolio at risk (PAR) & $0.0454529(2.80)^{* * *}$ & $-0.1821369(-4.45)^{* *}$ & $0.0087776(0.52)$ \\
\hline Borrower per staff member (BSM) & $-0.1261982(-7.06) * * *$ & $0.3877897(8.53)^{* * *}$ & $0.0201617(1.08)$ \\
\hline Yield on gross loan portfolio (YLD) & $-0.0578539(-2.23)^{* *}$ & $0.0416677(0.62)$ & $0.0378718(1.39)$ \\
\hline Gross loan portfolio (GLP) & $0.0852472(4.53)^{* * *}$ & $0.6006268(14.38)^{* * *}$ & $-0.0100927(-0.58)$ \\
\hline Operating expense to assets ratio (OEA) & $-0.0533091(-2.56) * * *$ & $0.0595972(1.10)$ & $0.0994478(4.51)^{* * *}$ \\
\hline Return on equity (ROE) & $0.0064736(1.35)$ & $-0.0065369(-0.52)$ & $0.00481(0.94)$ \\
\hline Return on assets (ROA) & $-0.0187997(-2.57) * * *$ & $0.0317405(1.64)$ & $-0.03492(-4.34) * * *$ \\
\hline Intercept & $-0.6926289(-5.11)^{* * *}$ & $-0.7843124(-2.66) * * *$ & $-0.1077301(-0.88)$ \\
\hline sigma_u & 0.31824549 & 0.32651779 & 0.14610204 \\
\hline sigma_e & 0.20291035 & 0.55471993 & 0.22404889 \\
\hline Rho & 0.71097367 & 0.25731751 & 0.29836035 \\
\hline R-square & 0.2834 & 0.5040 & 0.0892 \\
\hline Wald-statistic & $\begin{array}{c}\text { Chi2 } 2(8)=100.45 \\
\text { Prob }>\text { chi2 }=0.0000\end{array}$ & $\begin{array}{c}\text { Chi2 }(8)=334.51 \\
\text { Prob }>\text { chi2 }=0.0000\end{array}$ & $\begin{array}{c}\text { Chi } 2(8)=48.70 \\
\text { Prob }>\text { chi2 } 2=0.0000\end{array}$ \\
\hline
\end{tabular}

Source: Estimation based on MIX market data

Significance level: $* * *,<0.01 ; * *,<0.05 ; *,<0.10$. 
to control PAR so as to improve loan portfolio quality thus appears relevant from the analysis.

Furthermore, the results show that BSM significantly influences depth of outreach negatively but has a positive influence on the breadth of outreach (NAB). The intuition is that MFIs are less productive in their efforts in serving the core poor than dealing with poor clients. The remoteness of location and time demands imposed on both clients and staff could account for this. These results are very revealing as previous studies did not closely examine the link between depth and breadth of outreach. The results contribute to the microfinance outreach literature by giving more insights into the nature of trade-offs between depth and breadth of outreach using institutional level variables.

The YLD is negative and statistically significant as expected in the depth of outreach model. This confirms the classical welfarist perspective that rising interest rates will not only lead to the exclusion of the poor but will hurt outreach efforts made by institutions as the poor will be unable to afford the high-interest rates (Conning 1999). However, a positive association exists between YLD and breadth of outreach, though statistically insignificant. Furthermore, GLP positively influences both depth and breadth of outreach as expected. This means that as the loan portfolio of an MFI increases, its outreach prospects improve, though focusing on females appears insignificant. This result is in line with Kar (2013) who found positive significant links between MFI size and depth of outreach.

OEA ratio is negative and significantly related to the depth of outreach. This shows that rising operating costs have negative consequences in extending financial services to core poor clients. However, a positive significant relation exists between OEA and percentage of females served (PFB), suggesting that reaching out to more female borrowers increases the operating expenses of MFIs. This result confirms that of Hermes et al. (2011) who find lending to women inefficient. In addition, ROA is significant and relates negatively to both depth and breadth of outreach as measured by PFB contrary to our expectation. This suggests portfolio diversification, a situation where MFIs instead of augmenting lending to the poor invest in other assets perceived to yield higher returns. As MFIs experience positive returns on their investments, the profits are channelled to other investments at the expense of reaching out to many poor clients with the needed products and services. The observed higher operating costs that plague most MFIs in the sector could also account for this situation. This result supports the findings of Mersland and Strom (2016) that MFIs struggle with higher costs and lower earnings.

Findings from the study show that GLP and PAR are the main factors that positively influence the depth of outreach of MFIs in SSA. The level of staff productivity (BSM), lending interest rate (YLD), operating expenses (OEA) and ROA negatively affect outreach depth. On the other hand, model
[2] shows that staff productivity (BSM) and GLP positively drive MFIs' breadth of outreach. MFIs outreach to female clients is seen to be positively influenced by the OEA and returns on equity. The results show that using the number of borrowers appears to be a better predictor of MFI wider outreach in SSA than the proportion of females reached.

\section{Conclusions}

This study has highlighted the trade-off between the depth and breadth of outreach as well as the institutional factors that drive microfinance outreach with a focus on SSA. The study used correlation and RE regression methodology to show the outreach performance of MFIs. Our results provide supportive evidence to the higher operating costs proposition for MFIs in the industry. Evidently, most institutions still struggle to cover their costs with little returns and serving female clients appears to be inefficient. This has implications for industry sustainability, efficiency and outreach to the poor. Furthermore, the results show convincingly that a trade-off exists between the depth and breadth of outreach of MFIs in the region. This has clear policy implication: MFIs that focus attention on reaching the relatively poor with financial services are likely to miss out in their effort to reach a large number of borrowers. This highlights the cost implication involved in reaching the poor and designing financial products that meet their needs.

Furthermore, the study revealed a number of institutional level factors that strongly influence the outreach performance of institutions. The main drivers of MFIs outreach are the GLP, the interest rate, OEA, ROA and ROE. While the PAR only drives MFIs depth of outreach, staff productivity impacts on only the breadth dimension of outreach.

\section{Recommendations}

The main recommendations emanating from the study are twofold: for the management of MFIs and policy review. The study recommends that managers of MFIs should make conscious efforts and create a balance in the attainment of the social goals of the institutions in accomplishing both the depth and breadth dimensions of outreach. This calls for proper planning and efficient goal monitoring from management. Periodic analysis of outreach data at the firm level needs to be given a high priority to supporting timely decision-making in setting realistic outreach targets and effective monitoring of planned activities implemented. Low cost of outreach but efficient technologies (e.g. M-Pesa) should be adopted to help reduce cost, improve outreach and sustain MFIs operations.

Furthermore, there is a need for a policy on interest rate regulation not to worsen the limited access situation of poor people to financial services. Higher interest rates by MFIs can cripple the entire microfinance sector if nothing is done to regulate the system. In addition, governments should increase budgetary allocations to the microfinance sector for the benefit of the poor. 


\section{Acknowledgements Competing interests}

The authors declare that they have no financial or personal relationships which may have inappropriately influenced them in writing this article.

\section{Authors' contributions}

A.A. was responsible for research design, data gathering, data analysis and report writing while D.D.T. was in charge of supervision, editing, and review.

\section{References}

Adhikary, S. \& Papachristou, G., 2014, 'Is there a trade-off between financial performance and outreach in South Asian microfinance institutions?', The Journa of Developing Areas 48(4), 381-402. http://dx.doi.org/10.1353/jda.2014.0081

African Union, 2009, 'Advancing the African Microfinance Sector, Follow-up to the African Microfinance Roadmap', paper presented at the Extraordinary Conference of African Ministers of Economy and Finance, CAME, Addis Ababa, Ethiopia, 11th December.

Ahlin, C., Lin, J. \& Maio, M., 2011, 'Where does microfinance flourish? Microfinance institutions' performance in macroeconomic context', Journal of Development Economics 95, 105-120. http://dx.doi.org/10.1016/j.jdeveco.2010.04.004

Awusabo-Asare, K., Annim, S.K., Abane, A.M. \& Asare-Minta, D., 2009, 'Who is reaching whom? Depth of outreach of rural microfinance institutions in Ghana', International NGO Journal 4(4), 132-141.

Bateman, M., 2014, South Africa's post-apartheid microcredit-driven calamity: Comparing "developmental" to "anti-developmental" local finance models, Working Paper No. WP 47, Australia Foundation for Development Research, viewed 03
September 2014, from http://www.oefse.oat/downloads/publikationen/WP47_ south_africa.pdf

Bos, J.W.B. \& Millone, M., 2014, 'Practice what you preach: Microfinance business models and operational efficiency', World Development 70, 28-42. http://dx.doi. org/10.1016/j.worlddev.2014.12.018

Brooks, C., 2008, 'Introductory econometrics for finance', 3rd edn., Cambridge University Press, Cambridge.

CGAP, 2005, Crafting money transfers strategy: Guidance for pro-poor services providers, Occasional Paper No. 10, World Bank, Washington, DC.

CGAP, 2010, The state of financial inclusion through the crises, financial access 2010 World Bank, Washington, DC.

CGAP, 2012, Sub-Saharan Africa Snapshot, Consultative Group to Assist the Poor, Washington, DC.

Conning, J., 1999, 'Outreach, sustainability and leverage in monitored and peer monitored lending', Journal of Development Economics 60(1), 51-77. http://dx. doi.org/10.1016/S0304-3878(99)00036-X

Crabb, P., 2008, 'Economic freedom and the success of microfinance institutions', Journal of Developmental Entrepreneurship 13(2), 205-219. http://dx.doi. org/10.1142/S1084946708000934

Cull, R., Demirguc-Kunt, A. \& Morduch, J., 2007, 'Financial performance and outreach: A global analysis of leading micro banks', Economic Journal 117, F107-F133. http://dx.doi.org/10.1111/j.1468-0297.2007.02017.x

Cull, R., Demirguc-Kunt, A. \& Morduch, J., 2009, 'Microfinance meets the market' Journal of Economic Perspectives 23(1), 167-192. http://dx.doi.org/10.1257/ jep.23.1.167

Greene, W.H., 2005, Econometric analysis, 5th edn., Prentice Hall, Upper Saddle River, NJ.

Hartarska, V., 2005, 'Governance and performance of microfinance institutions in Central and Eastern Europe and the Newly Independent States', World Development 33(10), 1627-1643. http://dx.doi.org/10.1016/j.worlddev.2005.06.001

Hartarska, V. \& Nadolnyak, D., 2007, 'Do regulated microfinance institutions achieve better sustainability and outreach? Cross-country evidence', Applied Economics 39, 1207-1222. http://dx.doi.org/10.1080/00036840500461840

Hermes, N. \& Lensink, R., 2011, 'Microfinance: Its impacts, outreach, and sustainability', World Development 39(6), 875-881. http://dx.doi.org/10.1016/j. worlddev.2009.10.021

Hermes, N., Lensink, R. \& Meesters, A., 2011, 'Outreach and efficiency of microfinance institutions', World Development 39(6), 938-948. http://dx.doi.org/10.1016/j. worlddev.2009.10.018

Honohan, P. \& Beck, T., 2007, Making finance work for Africa, The World Bank, Washington, DC

Hudak, K., 2012, 'What next for microfinance? How the broader financial contex matters for effective microfinance outreach', Journal of Developmental Entrepreneurship 17(4), 1-19. http://dx.doi.org/10.1142/S1084946712500239
Imai, K.S., Gaiha, R., Thepa, G., Annim, S.K. \& Gupta, A., 2012, Performance of microfinance institutions: A macroeconomic and institutional perspective, Research microfinance institutions: A macroeconomic and institutional perspective, Res
Institute of Economics and Business Administration, Kobe University, Kobe.

Jegede, C.A., Kehinde, J.S. \& Akinlabi, B.H., 2012, 'Trends of outreach and sustainability of microfinance institutions in Southwestern Nigeria', International Trade \& Academic Research Conference (ITARC), London, UK, 7-8th November 2012.

Jensen, M.K., 2003, 'On Alternative theories of savings', Journal of Economic Literature 34, 647-661.

Kai, H. \& Hamori, S., 2009, 'Globalization, financial deepening and inequality in SubSaharan Africa', Economics Bulletin 29(3), 2025-2037.

Kar, A.K., 2013, 'Mission drift in microfinance: Are the concerns really worrying? Recent cross country results', International Review of Applied Economics 27(1), 44-60. http://dx.doi.org/10.1080/02692171.2012.700701

Ledgerwood, J., 1999, Microfinance handbook: An institutional and financia perspectives, World Bank, Washington, DC.

Ledgerwood, J. \& White, V., 2006, Transforming microfinance institutions: Providing full financial services to the poor, The World Bank, Washington, DC.

Mersland, R. \& Strom, R.O., 2016, 'Microfinance: Costs, lending rates, and profitability', in G. Caprio, Jr., W.D. Arner, T. Beck, C.W. Calomiris, L. Neal \& N. Veron (eds.) Handbook of key global financial markets, institutions, and infrastructure, pp. 489-499, Elsevier Inc., Oxford, UK.

Morduch, J., Hashemi, S. \& Littlefield, E., 2003, Is microfinance an effective strategy to reach the millennium development goals?, CGAP Focus Note 24, Consultative Group to Assist the Poor, Washington, DC

Mori, N., Golesorkhi, S., Randoy, T. \& Hermes, N., 2015, 'Board composition and outreach performance of microfinance institutions: Evidence from East Africa', Strategic Change 24, 99-113. http://dx.doi.org/10.1002/jsc.2000

Navajas, S., Schreiner, M., Meyer, R.L., Gonzalez-Vega, C. \& Rodriguez-Meza, J., 2000, 'Microcredit and the poorest of the poor: Theory and evidence from Bolivia', World Development 28(2), 333-346. http://dx.doi.org/10.1016/S0305-750X(99)00121-7

Okumu, L.J., 2007, 'The Microfinance Industry in Uganda: Sustainability, outreach, and regulation', Unpublished Ph.D. Thesis, Stellenbosch University.

Osotimehin, K.O., Jegede, C.A. \& Akinlabi, B.H., 2011, 'Determinants of microfinance outreach in South-Western Nigeria: An empirical analysis', International Journal of Management and Business Studies 1(1), 001-007.

Oteng-Abayie, E., Amanor, K. \& Frimpong, J., 2011, 'The measurement and determinants of economic efficiency of microfinance institutions in Ghana: A stochastic frontier approach', African Review of Economics and Finance 2, 149-166.

Paxton, J., 2002, Depth of Outreach and its relation to the sustainability of microfinance institutions. Savings and Development 26(1), 69-86.

Piot-Lepetit, I. \& Nzongang, J., 2014, 'Sustainability, outreach to the poor and bestpractices of microfinance institutions within a network of Village Banks: The case of $\mathrm{MC}^{2}$ in Cameroon', European Journal of Operational Research 234(1), 319-330. http://dx.doi.org/10.1016/j.ejor.2013.10.004

Quayes, S., 2012, 'Depth of outreach and financial sustainability of microfinance institutions', Applied Economics 44, 3421-3433. http://dx.doi.org/10.1080/00036 846.2011.577016

Rao, A., 2002, 'Estimation of efficiency, scale and scope and productivity measures of United Arab Emirates Banks', paper presented at the European Conference of Financial Management Association International (FMAI-USA), Copenhagen, Denmark, 6th June 2002

Sagamba, M., Shchetinin, O. \& Nurmukhammed, Y., 2013, 'Do microloan officers want to lend to the less disadvantaged? Evidence from a choice experiment', World Development 42, 182-198. http://dx.doi.org/10.1016/j.worlddev.2012.06.019

Schreiner, M., 2002, 'Aspects of outreach: A framework for discussion of the social benefits of microfinance', Journal of International Development 14, 591-603. http://dx.doi.org/10.1002/jid.908

Stock, J.H. \& Watson, M.W., 2007, 'Why has U.S inflation become harder to forecast?', Journal of Money, Credit, and Banking 39(1), 3-33. http://dx.doi.org/10.1111/j. 1538-4616.2007.00014.x

Togba, E.L., 2012, 'Microfinance and households access to credit: Evidence from Cote d'Ivoire', Structural Change and Economic Dynamics 23, 473-486. http://dx.doi. org/10.1016/j.strueco.2012.08.002

Vanroose, A., 2008, 'What macro factors make microfinance institutions reach out?', Savings and Development 32(3), 153-174.

Vanroose, A. \& D'Espallier, B., 2013, 'Do microfinance institutions accomplish their mission? Evidence of the relationship between traditional financial sector development and microfinance institutions' outreach and performance', Applied Economics 45, 1965-1982. http://dx.doi.org/10.1080/00036846.2011.641932

Wydick, B., Karp, H. \& Hilliker, S., 2011, 'Social networks, neighbourhood effects, and credit access: Evidence from Rural Guatemala', World Development 39(6), 974-982. http://dx.doi.org/10.1016/j.worlddev.2009.10.015

Yaron, J., 1992, Successful rural finance institutions, Discussion Paper No. 150, The World Bank, Washington, DC.

Youssoufou, C., 2000, Performance of microfinance institutions in Burkina Faso, WIDER Discussion Papers//World Institute for Development Economics (UNU WIDER), No. 2002/01, ISBN 9291210, The United Nations University, Helsinki.

Zerai, B. \& Rani, L., 2011, 'Is there a Trade-off between outreach and sustainability of microfinance institutions? Evidence from Indian microfinance institutions', Research Journal of Finance and Accounting 2(11), 2222-2847. 


\section{Appendix 1}

TABLE 1-A1: List of microfinance institutions and countries included in the study.

\begin{tabular}{|c|c|c|c|}
\hline \multicolumn{2}{|l|}{ Ghana } & \multicolumn{2}{|l|}{ Benin } \\
\hline APED & ID Ghana & ACFB & MDB \\
\hline ASA Initiative & KSF & ALIDA & PADME \\
\hline CFF & OISL & CMMB & PARME \\
\hline First Allied Savings and Loans & Snapi Aba Trust & FACECAM & Vital Finance \\
\hline Grameen Ghana & WWB Ghana & RENECA & \\
\hline Burkina Faso & & South Africa & \\
\hline GRAIN Sarl & $\mathrm{RCPB}$ & Capitec Bank & SEF-ZAF \\
\hline LSK & & Opportunity Finance & SIZA Capital \\
\hline Nigeria & & Kenya & \\
\hline Access Bank & AMfB & BIMAS & KPOSB \\
\hline Grooming Centre & $D^{\prime} E C$ & Equity Bank & KWFT \\
\hline Hasal MFB & LEPO & Faulu MFB & Opportunity- Kenya \\
\hline \multirow[t]{3}{*}{ SEAP } & & Juhudi Kilimo & PAWDEP \\
\hline & & K-Rep & SMEP \\
\hline & & & SISDO \\
\hline Uganda & & Cameroon & \\
\hline BRAC-Uganda & UGAFODE & $\mathrm{A} 3 \mathrm{C}$ & CEC-PROM mature \\
\hline FINCA-Uganda & Finance Trust & CamCCUL & SOFINA \\
\hline Vision Fund Uganda & & $\mathrm{MCA}^{2}$ & RENAPRO \\
\hline Ethiopia & & Tanzania & \\
\hline $\mathrm{ASCl}$ & Gasha & BRAC-TZA & Opportunity-TZA \\
\hline Buusaa Gonofaa & SFPI & FINCA-TZN & SEDA \\
\hline Eshet & Wasasa & & \\
\hline PEACE & & & \\
\hline
\end{tabular}

